\title{
Exergy analysis of petroleum refinery hydrogen network integration based on reaction system
}

\author{
Ozben Kutlü,*, Fatma Zehra Ozcelik ${ }^{1}$ \\ ${ }^{1}$ Institute of Solar Energy, Ege University, 35100, Bornova, Izmir, Turkey, ozben.kutlu@ege.edu.tr, ORCID: 0000-0002- \\ 0361-6949 \\ ${ }^{2}$ Chemical Engineering Department, Ege University, 35100, Bornova, Izmir, Turkey, zehra.ozcelik@ege.edu.tr, ORCID: \\ 0000-0001-9470-4161
}

\section{A B S T R A C T}

High-purity hydrogen is a crucial input in a crude oil refinery to upgrade several products. For this reason, the effective hydrogen management is necessary to satisfy hydrogen requirements. On the other hand, adding exergy analysis to the hydrogen pinch analysis especially for refinery plants, where hydrogen reacts under high temperature and pressure, helps improve the efficiency of unit by overcoming the lack of pinch analysis. The aim of this study is the simulation and exergy analysis of reactors within hydrogen network integration of a petroleum refinery retrofitted by pinch analysis before. Two hydrogen production and four consumption units were considered and simulated by Aspen Plus, and then the exergy efficiencies were calculated. Low exergy efficiencies were determined in the hydrogen production and hydrodesulfurization units, whereas the separation of excess hydrogen from the desired product considerably effected on the efficiency. The results also show that not only the hydrogen demand of reactors has to be reduced, but also the hydrogen recovery and purification is very important for the increase in efficiency. Although the processes are carried out at the high operating conditions, the reactions significantly affect the total exergy flow rate

\section{ARTICLE INFO}

\section{Research article}

Received: 08.10.2020

Accepted: 25.02.2021

Keywords:

exergy,

hydrogen network, petroleum refinery, modeling and simulation

${ }^{*}$ Corresponding author

$\begin{array}{ll}\text { Nomenclature } \\ \mathrm{C} & \text { carbon } \\ \mathrm{C}_{12} \mathrm{H}_{22} & \text { bicyclohexyl } \\ \mathrm{C}_{12} \mathrm{H}_{8} \mathrm{~S} & \text { dibenzothiophene } \\ \mathrm{C}_{2} \mathrm{H}_{6} & \text { ethane } \\ \mathrm{C}_{2} \mathrm{H}_{6} \mathrm{~S} & \text { ethyl-mercaptans } \\ \mathrm{C}_{2} \mathrm{H}_{6} \mathrm{~S}_{2} & \text { dimethyl-disulfide } \\ \mathrm{C}_{3} \mathrm{H}_{8} & \text { propane } \\ \mathrm{C}_{4} \mathrm{H}_{10} & \text { butane } \\ \mathrm{C}_{4} \mathrm{H}_{4} \mathrm{~S} & \text { thiophene } \\ \mathrm{C}_{4} \mathrm{H}_{8} & \text { cyclobutane } \\ \mathrm{C}_{5} \mathrm{H}_{10} & \text { cyclopentane } \\ \mathrm{C}_{5} \mathrm{H}_{12} & \text { pentane } \\ \mathrm{C}_{6} \mathrm{H}_{12} & \text { methyl-cyclopentane or cyclohexane } \\ \mathrm{C}_{6} \mathrm{H}_{14} & \text { 2-methyl-pentane or 2,3-dimethyl-butane } \\ \mathrm{C}_{6} \mathrm{H}_{6} & \text { benzene } \\ \mathrm{C}_{7} \mathrm{H}_{14} & \text { methyl-cyclohexane } \\ \mathrm{C}_{7} \mathrm{H}_{16} & \text { heptane } \\ \mathrm{C}_{8} \mathrm{H}_{16} & \text { ethyl-cyclohexane } \\ \mathrm{C}_{8} \mathrm{H}_{18} & \text { octane } \\ \mathrm{C}_{8} \mathrm{H}_{6} \mathrm{~S} & \text { benzothiophene } \\ \mathrm{CH}_{4} & \text { methane }\end{array}$

$\begin{array}{ll}\mathrm{CO} & \text { carbonmonoxide } \\ \mathrm{CO}_{2} & \text { carbondioxide } \\ \mathrm{H}_{2} & \text { hydrogen } \\ \mathrm{H}_{2} \mathrm{O} & \text { water } \\ \mathrm{H}_{2} \mathrm{~S} & \text { hydrogen sulphide } \\ \dot{E} & \text { exergy rate }(\mathrm{kJ}) \\ \dot{H} & \text { enthalpy rate }(\mathrm{kJ}) \\ \dot{S} & \text { entropy rate }(\mathrm{kJ}) \\ \dot{m} & \text { mass flow rate }(\mathrm{kg} / \mathrm{s}) \\ \bar{e}^{\text {ch }} & \text { standard chemical exergy }(\mathrm{kJ} / \mathrm{kg}) \\ \mathrm{x} & \text { mole fraction } \\ \mathrm{Subscripts} \\ 0 & \text { reference conditions } \\ \mathrm{k} & \text { component } \\ \text { ch } & \text { chemical } \\ \text { ph } & \text { physical } \\ \text { Acronyms } & \text { isomerization } \\ \text { ISO } & \text { naphtha hydrotreating } \\ \text { NHT } & \end{array}$


CCR continuous catalytic reformer

SMR steam-methane reforming

SSR semi-regen reformer

HDS hydrodesulfurization

HC hydrocracker

LVGO light vacuum gas oil

HVGO heavy vacuum gas oil

LPG liquefied petroleum gas

\section{Introduction}

In a petroleum refining process, crude oil is separated, converted and turned into salable valuable products by using hydrogen. While the main products are white products like gasoline and heavy products like fuel oil, naphtha is an intermediate product of the refinery and used to produce high quality gasoline. Naphtha can be produced at each step of complex, such as atmospheric distillation, hydrocracker, and fluid catalytic cracker. However, each refinery that processes unique composition of crude oil produces its own naphtha composition, which separates as light and heavy naphtha [1]. The naphtha mainly has paraffin-type hydrocarbons that have low octane number. It is possible to increase the octane number by rearranging the molecular structures of the paraffins without changing the carbon numbers, i.e. turning them into isoparaffins by means of isomerization (ISO) process. Isomerization reactions give an important pathway for high-octane components in the gasoline [2]. Separation and recovery of the unconverted normal paraffins from their isomers play another major role in isomerate octane quality [3]. For this process, the sulfur, oxygen and nitrogen compounds in the structure of the naphtha are first removed in the naphtha hydrotreating (NHT) units with the help of a suitable catalyst in a hydrogen environment [4].

After NHT, the light naphtha is upgraded in the ISO, whereas the heavy naphtha, typically contains $\mathrm{C} 7+$ hydrocarbons, is sent to the continuous catalytic reformer (CCR) unit to produce hydrogen used in refinery demand [5]. In addition, benzene, toluene and xylene form in the reformer effluent. Hydrogen recovery from CCR unit can satisfy the part of the hydrogen demand in refinery but other external sources are required. Most of the external hydrogen is manufactured either by steam-methane reforming (SMR) or by oxidation processes [6].

Environmental pollution has recently created severe fuel regulations that the levels of sulfur compounds in fuels must be limited to less than $10 \mathrm{ppm}[7,8]$. To meet this requirement, more efficient hydrodesulfurization (HDS) technology that remove the sulfur-containing compounds, such as mercaptans, thiophene $\left(\mathrm{C}_{4} \mathrm{H}_{4} \mathrm{~S}\right)$, dibenzothiophene $\left(\mathrm{C}_{12} \mathrm{H}_{8} \mathrm{~S}\right)$, and other polyaromatic derivatives, has been intensely needed [9]. Similar to naphtha, the sulfur compounds in kerosene and diesel as transportation fuels are also reacted with hydrogen and converted to hydrogen sulfide $\left(\mathrm{H}_{2} \mathrm{~S}\right)$ and other hydrocarbon products (ethylbenzene, butene, bicyclohexyl etc.). While mercaptans generally are present in naphtha, thiophene and other compounds having higher molecular size are situated in kerosene and diesel fuels [6].

Hydrocracker (HC) units is one of the hydrogen consumption units in refinery and uses high pressure hydrogen to upgrade heavier fractions into lighter, more valuable products, through carbon-carbon bond breaking and hydrogen addition [5]. The heavier unsaturated fractions obtained from the crude oil distillation, including residue, applies to hydrocracking and the main products have lower boiling points, are highly saturated, and generally range from heavy diesel to light naphtha.

Hydrogen management in refinery is a typical network issue, in which hydrogen sources need to be matched with hydrogen sinks. As hydrogen at high purity is a crucial input for these units mentioned, its production and consumption should be managed based on economic cost-driven analysis [10]. Since the late 1990s, current methodologies published in extensive researches, can be distinguished in two main categories, which are; (i) targeting and design for minimum hydrogen utility; (ii) mathematical programming for detailed design and retrofit [7]. Pinch based conceptual methodology first proposed by Alves in 1999 [11]. It is easy to understand and has the potential to improve the efficiency of the mathematical approach [12]. In addition to hydrogen pinch analysis, mathematical approach is to formulate the hydrogen network problem as a prevalent optimization problem, using a convenient mathematical programming language [13].

Hydrogen network integration via the pinch analysis approach has been known as an effective way of process optimization [14]. The network integration has become prevalent because of the economic concerns and sustainability. On the other hand, exergy analysis, which takes also into account irreversibility, is more applicable and much more powerful thermodynamic tool [15]. Energy utilization options are restricted by thermodynamic principles and exergy analysis identifies the location, the magnitude, and the sources of the thermodynamic inefficiencies in a thermal system [16]. Exergy analysis has been applied individually in many different hydrogen production systems [17-21]. Although the exergy applications on the NHT process also performed [2225], each model is a unique due to the unique naphtha composition and simulation. While the exergy analysis of cracking and reforming units has been performed in these models, light-naphtha has been assessed together with heavy naphtha, or only n-heptane has been choosen as a model compound [26-29].

Even though lots of pinch analysis studies on the refinery also performed [7, 30-32], the addition of exergy analysis to hydrogen network has been a new trend for the last years [3335]. To improve the heat integration efficiency of refinery plant units, the exergy was used instead of enthalpy in pinch analysis [36, 37]. Lou et al. [12] developed the entropy change-based design method for multi-contaminant hydrogen 
network by using mathematical approach. Though Wu et al. [38] minimized the number of compressors and total exergy consumption in the refinery hydrogen distribution system, reactors in the network were not taken into account. The exergy as energy performance, environment issue and cost were generally selected as optimization objectives in other previous researches [33, 35].

In typical hydrogen management exercises, the partial pressure of hydrogen is assumed to be constant, as well as other parameters such as reactor feedstock, products, operating temperature, etc. However, the partial pressure in a reactor is a significant parameter for the reaction [7]. Under these approach, the efficiency of the reactor may not be assessed merely by hydrogen pinch analysis. Adding exergy analysis to the hydrogen pinch analysis especially for refinery plants, where hydrogen reacts under high temperature and pressure, will help improve this situation.

In this study, the exergy analysis is performed to current hydrogen network of a petroleum refinery retrofitted by hydrogen pinch analysis before. As the difference from other studies, it is assessed exergy loss of reactors in the hydrogen network. The energy and mass saving in related rafinery was supplied before, and this present study focuses on the reactors especially for investigating the energy bottlenecks. At this point, the exergy analysis applied easily to various systems, is most proper tool able to detect any source of this inefficiency.
In other words, it is target to ascertain undetected unit/units that could be created any energy bottleneck at the refinery hydrogen network. The simulation of network, in which hydrogen sources were matched with hydrogen sinks, is first created and then exergetic efficiency of entire reactors is evaluated. Two hydrogen production and four consumption units are designed by Aspen Plus V8 based on the operating feed rates of hydrogen, and so each exergetic efficiency of the reactors are calculated.

\section{Process and methods}

\section{Process Description}

The flowsheet of units in the hydrogen network corresponds to the actual petroleum refinery. However, appropriate changes and assumptions in the process have been made, taking into account privacy policies. In this sense, the hydrogen network comprises of all units that consume or produce the hydrogen. This network is divided into two production units and four main consumer units (Figure 1). While the hydrogen is consumed in hydrotreating, isomerization, hydrodesulphurization and hydrocracking units, catalytic and steam reformer units contribute to these units by hydrogen production. The general flowsheet of hydrogen network is given in Figure 1 and the exergy analysis has been conducted in the boundary of each unit shown as red dashed line. 


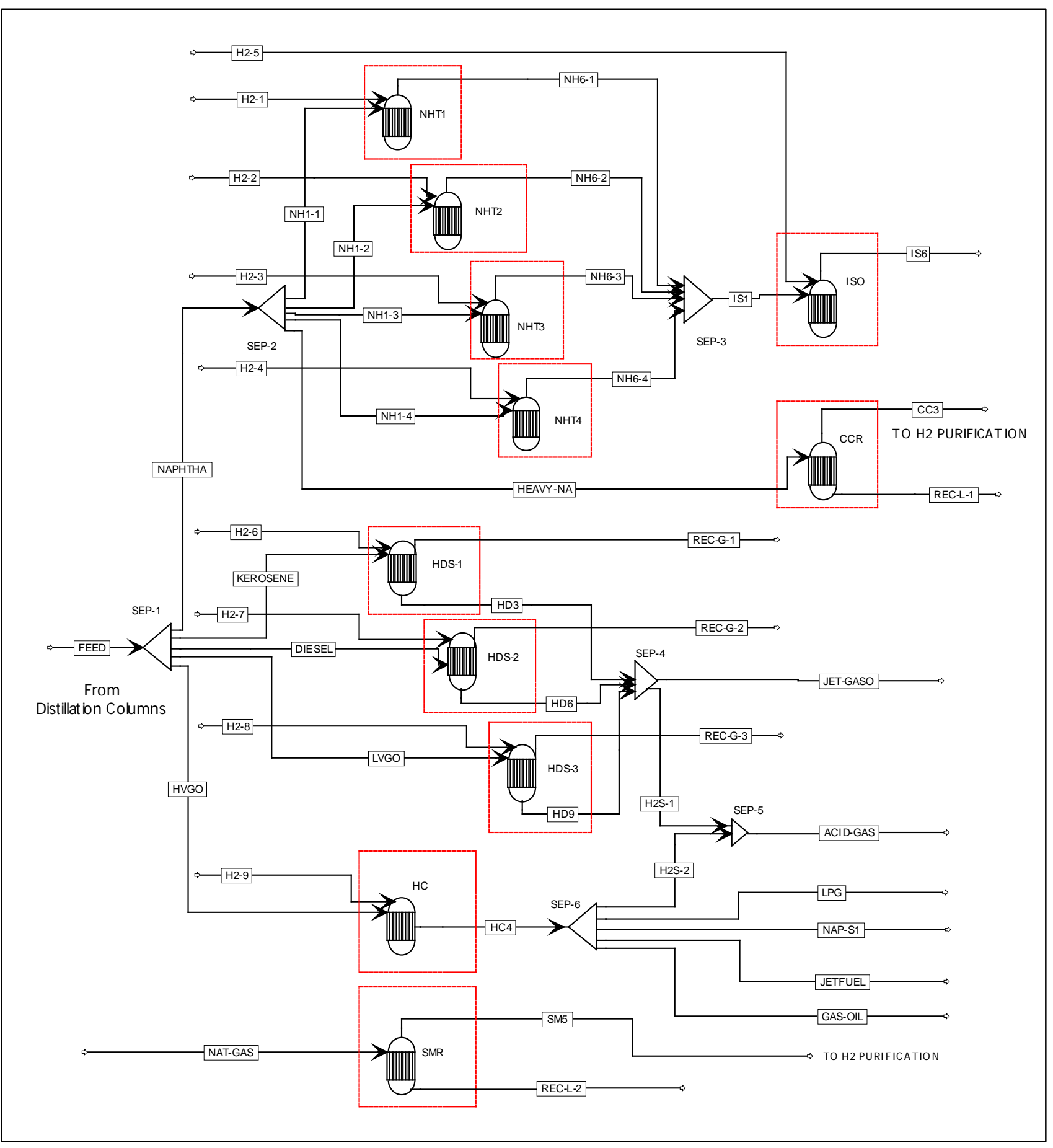

Figure 1. Flowsheet of reactors on the petroleum refinery hydrogen network

Figure 1 is also shown the product distribution in the refinery plant generally. Crude oil, signified as feed in Figure 1, is mixture of hydrocarbon molecules containing C1 to C60. Naphtha, kerosene and diesel are mainly produced as side stream products by atmospheric distillation of crude oil, whereas light vacuum gas oil (LVGO in figure) and heavy vacuum gas oil (HVGO in figure) are produced by vacuum distillation unit. NHT and ISO processes are applied to crude light straight run naphtha (C4-C6) for removing undesired compounds and upgrading octane number. In the simulation, the desired products form in vapor phase for these units, and four NHT and one ISO reactors are present in the rafinery (Figure 1). The sulphur compounds in kerosene, diesel and LVGO are removed in the HDS units with the help of a suitable catalyst in a hydrogen environment, and the desired products is obtained in liquid stream. For these three 
products, three different HDS reactors are present in Figure 1. Moreover, HVGO is fed to the HC reactor operating at high pressure in hydrogen medium, to crack the heavy molecules into lighter molecular weight compounds, with boiling point ranging from LPG's to gas-oil's. The desired products leave from the cracker with hydrogen in the vapor stream. The compositions of entire feed and hydrogen streams are given in Table 1.

Table 1. The compositions of entire feed and hydrogen streams

\begin{tabular}{|c|c|c|c|}
\hline Unit & Feed & Composition (\%vol.) & $\mathrm{H}_{2}$ consumption (\%) \\
\hline \multirow{3}{*}{$\begin{array}{l}\text { NHT-1 } \\
\text { NHT-2 } \\
\text { NHT-3 } \\
\text { NHT-4 }\end{array}$} & Naphtha: $\mathrm{C}_{4} \mathrm{H}_{10} ; \mathrm{C}_{5} \mathrm{H}_{12} ; \mathrm{C}_{6} \mathrm{H}_{14}$ & 30; 30; 30 & \multirow{3}{*}{$\begin{array}{l}\mathrm{H}_{2}: 70 \% ; \mathrm{CH}_{4}: 18 \% \\
\mathrm{C}_{2} \mathrm{H}_{6}: 10 \% ; \mathrm{C}_{3} \mathrm{H}_{8}: 2 \%\end{array}$} \\
\hline & $\mathrm{C}_{4} \mathrm{H}_{8} ; \mathrm{C}_{5} \mathrm{H}_{10} ; \mathrm{C}_{6} \mathrm{H}_{12} ; \mathrm{C}_{6} \mathrm{H}_{6}$ & $1.4 ; 1.4 ; 1.4 ; 1.8$ & \\
\hline & $\mathrm{C}_{2} \mathrm{H}_{6} \mathrm{~S} ; \mathrm{C}_{2} \mathrm{H}_{6} \mathrm{~S}_{2}$ & $2 ; 2$ & \\
\hline ISO & NHT outlet & & $\begin{array}{l}\mathrm{H}_{2}: 90 \% ; \mathrm{CH}_{4}: 6 \% \\
\mathrm{C}_{2} \mathrm{H}_{6}: 3 \% ; \mathrm{C}_{3} \mathrm{H}_{8}: 1 \%\end{array}$ \\
\hline \multirow[t]{2}{*}{ HDS-1 } & $\begin{array}{l}\text { Kerosene: n-C9; n-C10; n-C11; n-C12; n-C13; n- } \\
\text { C14; n-C15; n-C16; }\end{array}$ & Each comp. 12.2 & \multirow{2}{*}{$\begin{array}{l}\mathrm{H}_{2}: 70 \% ; \mathrm{CH}_{4}: 18 \% \\
\mathrm{C}_{2} \mathrm{H}_{6}: 10 \% ; \mathrm{C}_{3} \mathrm{H}_{8}: 2 \% \\
\end{array}$} \\
\hline & $\mathrm{C}_{2} \mathrm{H}_{6} \mathrm{~S} ; \mathrm{C}_{2} \mathrm{H}_{6} \mathrm{~S}_{2} ; \mathrm{C}_{4} \mathrm{H}_{4} \mathrm{~S} ; \mathrm{C}_{8} \mathrm{H}_{6} \mathrm{~S} ; \mathrm{C}_{12} \mathrm{H}_{8} \mathrm{~S}$ & Each comp. 0.5 & \\
\hline \multirow{2}{*}{ HDS-2 } & Diesel: n-C18; n-C20; & $47.5 ; 50$ & \multirow{2}{*}{$\begin{array}{l}\mathrm{H}_{2}: 70 \% ; \mathrm{CH}_{4}: 18 \% \\
\mathrm{C}_{2} \mathrm{H}_{6}: 10 \% ; \mathrm{C}_{3} \mathrm{H}_{8}: 2 \%\end{array}$} \\
\hline & $\mathrm{C}_{2} \mathrm{H}_{6} \mathrm{~S} ; \mathrm{C}_{2} \mathrm{H}_{6} \mathrm{~S}_{2} ; \mathrm{C}_{4} \mathrm{H}_{4} \mathrm{~S} ; \mathrm{C}_{8} \mathrm{H}_{6} \mathrm{~S} ; \mathrm{C}_{12} \mathrm{H}_{8} \mathrm{~S}$ & Each comp. 0.5 & \\
\hline \multirow{2}{*}{ HDS-3 } & LVGO: n-C25; & 96; & \multirow{2}{*}{$\begin{array}{l}\mathrm{H}_{2}: 85 \% ; \mathrm{CH}_{4}: 9 \% \\
\mathrm{C}_{2} \mathrm{H}_{6}: 5 \% ; \mathrm{C}_{3} \mathrm{H}_{8}: 1 \%\end{array}$} \\
\hline & $\mathrm{C}_{2} \mathrm{H}_{6} \mathrm{~S} ; \mathrm{C}_{2} \mathrm{H}_{6} \mathrm{~S}_{2} ; \mathrm{C}_{4} \mathrm{H}_{4} \mathrm{~S} ; \mathrm{C}_{8} \mathrm{H}_{6} \mathrm{~S} ; \mathrm{C}_{12} \mathrm{H}_{8} \mathrm{~S}$ & Each comp. 0.8 & \\
\hline \multirow{2}{*}{$\mathrm{HC}$} & HVGO: n-C30; & 95; & \multirow{2}{*}{$\begin{array}{l}\mathrm{H}_{2}: 90 \% ; \mathrm{CH}_{4}: 6 \% \\
\mathrm{C}_{2} \mathrm{H}_{6}: 3 \% ; \mathrm{C}_{3} \mathrm{H}_{8}: 1 \%\end{array}$} \\
\hline & $\mathrm{C}_{2} \mathrm{H}_{6} \mathrm{~S} ; \mathrm{C}_{2} \mathrm{H}_{6} \mathrm{~S}_{2} ; \mathrm{C}_{4} \mathrm{H}_{4} \mathrm{~S} ; \mathrm{C}_{8} \mathrm{H}_{6} \mathrm{~S} ; \mathrm{C}_{12} \mathrm{H}_{8} \mathrm{~S}$ & Each comp. 1 & \\
\hline \multirow{2}{*}{ CCR } & Heavy Naphtha: $\mathrm{C}_{6} \mathrm{H}_{12} ; \mathrm{C}_{7} \mathrm{H}_{14} ; \mathrm{C}_{8} \mathrm{H}_{16}$; & $1 ; 21 ; 46$ & \multirow{2}{*}{-} \\
\hline & $\mathrm{C}_{6} \mathrm{H}_{14} ; \mathrm{C}_{7} \mathrm{H}_{16} ; \mathrm{C}_{8} \mathrm{H}_{18}$ & 19; 8; 5 & \\
\hline SMR & Natural gas: $\mathrm{CH}_{4}$ & 100 & - \\
\hline
\end{tabular}

High-quality hydrogen is consumed during the HC reactions, and thus SMR is used to satisfy the demand. For production of hydrogen, natural gas is fed to the reactor and the desired product in vapor phase goes to the purification section (Figure 1 ). Even though the high-quality hydrogen is also used for other consumer processes, CCR and semi-regen reformer (SRR) are main units in the hydrogen network to produce hydrogen. By using CCR and SRR, hydrotreated heavy straight run naphtha (C6-C8) is converted to hydrogen. In this simulation, CCR unit is selected due to produce higher-quality and -capacity hydrogen than SRR in the simulated plant. The compositions of entire feed and hydrogen streams are also chosen within actual refinery data and prototype calculations are carried out. The process conditions and chemical reactions in each unit are given in Table 2 and Table 3.
Table 2. The operating conditions of each unit

\begin{tabular}{lcccc}
\hline Unit & $\begin{array}{c}\text { Temp. } \\
\left({ }^{\circ} \mathbf{C}\right)\end{array}$ & $\begin{array}{c}\text { Pressure } \\
\left(\mathbf{k g} / \mathbf{c m}^{2} \mathbf{g}\right)\end{array}$ & $\begin{array}{c}\text { Flow } \\
\mathbf{r a t e s} \\
\left(\mathbf{m}^{\mathbf{3}} \mathbf{h}\right)\end{array}$ & $\begin{array}{c}\mathbf{H}_{\mathbf{2}} \text { Flow } \\
\text { rates } \\
\left(\mathbf{m}^{\mathbf{3}} / \mathbf{h}\right)\end{array}$ \\
\hline NHT-1 & 200 & 30 & 60 & 600 \\
NHT-2 & 200 & 30 & 150 & 1500 \\
NHT-3 & 200 & 30 & 100 & 1000 \\
NHT-4 & 200 & 30 & 60 & 2100 \\
ISO & 130 & 30 & 100 & 4500 \\
HDS-1 & 340 & 35 & 50 & 2500 \\
HDS-2 & 340 & 35 & 50 & 2500 \\
HDS-3 & 340 & 65 & 400 & 40000 \\
HC & 390 & 155 & 120 & 37200 \\
CCR & 520 & 42 & 150 & - \\
SMR & 840 & & & - \\
\hline
\end{tabular}


Table 3. The reactions defined for each unit

\begin{tabular}{|c|c|c|c|}
\hline Unit & Reactions & Unit & Reactions \\
\hline NHT & $\begin{array}{l}\mathrm{C}_{6} \mathrm{H}_{6}+3 \mathrm{H}_{2} \rightarrow \mathrm{C}_{6} \mathrm{H}_{12} \\
\mathrm{C}_{6} \mathrm{H}_{12}+\mathrm{H}_{2} \rightarrow \mathrm{C}_{6} \mathrm{H}_{14} \\
\mathrm{C}_{2} \mathrm{H}_{6} \mathrm{~S}+\mathrm{H}_{2} \rightarrow \mathrm{C}_{2} \mathrm{H}_{6}+\mathrm{H}_{2} \mathrm{~S} \\
\mathrm{C}_{2} \mathrm{H}_{6} \mathrm{~S}_{2}+3 \mathrm{H}_{2} \rightarrow 2 \mathrm{CH}_{4}+2 \mathrm{H}_{2} \mathrm{~S}\end{array}$ & SMR & $\begin{array}{l}\mathrm{CH}_{4}+\mathrm{H}_{2} \mathrm{O} \rightarrow \mathrm{CO}+3 \mathrm{H}_{2} \\
\mathrm{CO}+\mathrm{H}_{2} \mathrm{O} \leftrightarrows \mathrm{CO}_{2}+\mathrm{H}_{2}\end{array}$ \\
\hline ISO & $\begin{array}{l}C_{4} H_{8}+H_{2} \rightarrow \mathrm{n}-C_{4} H_{10} \\
C_{5} H_{10}+H_{2} \rightarrow \mathrm{n}-C_{5} H_{12} \\
C_{6} H_{12}+H_{2} \rightarrow \mathrm{n}-C_{6} H_{14} \\
n-C_{5} H_{10}+H_{2} \rightarrow \mathrm{CH}_{4}+\mathrm{n}-C_{4} H_{10} \\
\mathrm{n}-C_{4} H_{10} \leftrightarrows \mathrm{i}-C_{4} H_{10} \\
\mathrm{n}-C_{5} H_{12} \leftrightarrows \mathrm{i}-C_{5} H_{12} \\
n-C_{6} H_{14} \leftrightarrows \mathrm{i}-C_{6} H_{14} \text { (2-methyl-pentane) } \\
n-C_{6} H_{14} \leftrightarrows \mathrm{i}-C_{6} H_{14} \text { (2,3-dimethyl-butane) }\end{array}$ & CCR & $\begin{array}{l}\mathrm{C}_{6} \mathrm{H}_{12} \rightarrow \mathrm{C}_{6} \mathrm{H}_{6}+3 \mathrm{H}_{2} \\
\mathrm{C}_{7} \mathrm{H}_{14} \rightarrow \mathrm{C}_{7} \mathrm{H}_{8}+3 \mathrm{H}_{2} \\
\mathrm{C}_{8} \mathrm{H}_{16} \rightarrow \mathrm{C}_{8} \mathrm{H}_{10}+3 \mathrm{H}_{2} \\
\mathrm{C}_{6} \mathrm{H}_{14} \rightarrow \mathrm{C}_{6} \mathrm{H}_{6}+4 \mathrm{H}_{2} \\
\mathrm{C}_{6} \mathrm{H}_{14}+\mathrm{H}_{2} \rightarrow \mathrm{C}_{5} \mathrm{H}_{12}+\mathrm{CH}_{4} \\
\mathrm{C}_{7} \mathrm{H}_{16}+\mathrm{H}_{2} \rightarrow i-\mathrm{C}_{4} \mathrm{H}_{10}+\mathrm{C}_{3} \mathrm{H}_{8} \\
\mathrm{C}_{8} \mathrm{H}_{18}+\mathrm{H}_{2} \rightarrow n-\mathrm{C}_{4} \mathrm{H}_{10}+\mathrm{i}-\mathrm{C}_{4} \mathrm{H}_{10}\end{array}$ \\
\hline HDS & $\begin{array}{l}\mathrm{C}_{2} \mathrm{H}_{6} \mathrm{~S}+\mathrm{H}_{2} \rightarrow \mathrm{C}_{2} \mathrm{H}_{6}+\mathrm{H}_{2} \mathrm{~S} \\
\mathrm{C}_{2} \mathrm{H}_{6} \mathrm{~S}_{2}+3 \mathrm{H}_{2} \rightarrow 2 \mathrm{CH}_{4}+2 \mathrm{H}_{2} \mathrm{~S} \\
\mathrm{C}_{4} \mathrm{H}_{4} \mathrm{~S}+3 \mathrm{H}_{2} \rightarrow \mathrm{C}_{4} \mathrm{H}_{8}+\mathrm{H}_{2} \mathrm{~S} \\
\mathrm{C}_{8} \mathrm{H}_{6} \mathrm{~S}+3 \mathrm{H}_{2} \rightarrow \mathrm{C}_{8} \mathrm{H}_{10}+\mathrm{H}_{2} \mathrm{~S} \\
\mathrm{C}_{12} \mathrm{H}_{8} \mathrm{~S}+8 \mathrm{H}_{2} \rightarrow \mathrm{C}_{12} \mathrm{H}_{22}+\mathrm{H}_{2} \mathrm{~S}\end{array}$ & $\mathrm{HC}$ & $\begin{array}{l}C_{30} H_{62}+H_{2} \rightarrow n-C_{20} H_{42}+n-C_{10} H_{22} \\
C_{20} H_{42}+H_{2} \rightarrow n-C_{10} H_{22}+n-C_{10} H_{22} \\
C_{10} H_{22}+H_{2} \rightarrow n-C_{5} H_{12}+i-C_{5} H_{12} \\
C_{10} H_{22}+2 H_{2} \rightarrow n-C_{5} H_{12}+n-C_{4} H_{10}+C_{4} \\
C_{10} H_{22}+3 H_{2} \rightarrow i-C_{4} H_{10}+C_{3} H_{8}+C_{2} H_{6}+C_{4} \\
C_{2} H_{6} S+H_{2} \rightarrow C_{2} H_{6}+H_{2} S \\
C_{2} H_{6} S_{2}+3 H_{2} \rightarrow 2 C_{4}+2 H_{2} S \\
C_{4} H_{4} S+3 H_{2} \rightarrow C_{4} H_{8}+H_{2} S \\
C_{8} H_{6} S+3 H_{2} \rightarrow C_{8} H_{10}+H_{2} S \\
C_{12} H_{8} S+8 H_{2} \rightarrow C_{12} H_{22}+H_{2} S\end{array}$ \\
\hline
\end{tabular}

\section{Modeling of Hydrogen Network}

The cascaded units are simulated in software Aspen Plus V8. The sequential simulation is performed on the boundary of each unit and the inlet compositions are assumed by considering the actual rates of hydrogen feed. RK-SOAVE property method as the most suitable model for refinery applications is chosen. Because each refinery that processes unique composition of crude oil produces its own product composition, the base case of units is provided by the actual plant data at certain time depending on some appropriate changes in operating conditions. In case fractional conversion of reaction is known, RStoic reactor model is used in the modeling. Other case, rigorous equilibrium reactor (REquil) model is selected based on stoichiometric approach. The fractional conversion for the most of the reaction is chosen as minimum 0.90. However, n-hexane conversion to benzene in CCR, n-pentane conversion to methane and butane in ISO, and methylcyclopentane conversion to hexane in NHT are adjusted as $60 \%, 4 \%$ and $40 \%$, respectively. The outlet streams are cooled to $30^{\circ} \mathrm{C}$, and the pressure of streams drops to $5 \mathrm{~kg} \mathrm{~cm}^{-3}$ (g) so as to separate the desired product from hydrogen flow.

\section{Exergy Analysis}

Considering the exergy analysis for hydrogen network, the kinetic, potential, nuclear, magnetic, and electrical exergies are neglected; therefore, the total exergy rate of each stream is formed by sum of only chemical $\left(\mathrm{E}^{\mathrm{ch}}\right)$ and physical exergies $\left(\mathrm{E}^{\mathrm{ph}}\right)$. The physical exergy rates of streams are determined by Aspen Plus according to the general equation [39], while standard chemical exergy rates of any components in the gas mixture is taken from basis of Szargut's model [40]. As a result, the equations are given as

$$
\begin{aligned}
\dot{E}^{p h} & =\left(\dot{H}-\dot{H}_{0}\right)-T_{0}\left(\dot{S}-\dot{S}_{0}\right) \\
\dot{E}^{c h} & =\dot{m} \bar{e}^{c h}=\dot{m}\left[\sum x_{k} \bar{e}_{k}^{c h}+R T_{o} \sum x_{k} \ln x_{k}\right]
\end{aligned}
$$


where $\mathrm{H}$ is enthalpy flow rate, $\mathrm{S}$ is entropy flow rate, $\mathrm{m}$ is mass flow rate, $x_{k}$ is the mole fraction of $k_{\text {th }}$ component, $\bar{e}^{\text {ch }}$ is standard chemical exergy of $\mathrm{k}_{\text {th }}$ substance, $\mathrm{R}$ is gas constant, $\mathrm{T}$ is the temperature of the environment whose temperature and pressure are chosen as $298 \mathrm{~K}$ and $1 \mathrm{~atm}$ in present study. Though the standard chemical exergy of most compounds is taken from data of Szargut [40], by using Table II, the remains $\left(\mathrm{C}_{8} \mathrm{H}_{6} \mathrm{~S} ; \mathrm{C}_{12} \mathrm{H}_{8} \mathrm{~S}, \mathrm{C}_{12} \mathrm{H}_{22}, \mathrm{C} 18\right.$, C20, C21 and C30) have been calculated according to group contribution by using Table III in the same book. Moreover, the overall efficiency of each unit is calculated by the ratio of the exergy rate of desired outlet stream to that of inlet streams.

\section{Results and discussion}

The hydrogen network integration is the most important part of crude oil refinery plant because a lot of units consume the hydrogen-rich gas as both make-up gas and reactant. The hydrogen pinch analysis, which creates hydrogen network of a plant, reduces the hydrogen surplus by matching only the hydrogen streams. However, other compounds in the stream are not evaluated. To assess entire compounds, exergy analysis together with pinch analysis is more powerful thermodynamic tool in case the presence of various units. The proposed hydrogen network in this study is thermodynamically analyzed using exergetic approaches. This study creates the cascaded unit simulation with the help of main inlet streams and reactions and examines the network results. The main criteria of simulation were the hydrogen flow rate per unit feed capacity. While the inlet stream properties were assumed as unit operating conditions, the outlet stream were cooled at $30^{\circ} \mathrm{C}$ and expanded to 6 bars. The stream data of analysis results are given in Table 4. Even though the processes were carried out at the moderate and high operating conditions, the physical exergy flow rates of whole streams were significantly lower than chemical exergy rates. The change in composition between inlet and outlet (Table A1 to A3) by reactions considerably effected chemical exergy rate.

In the proposed network the consumption units of hydrogen consist of HC, HDS, NHT and ISO, whereas the production units are CCR and SMR. The exergy efficiencies of the production units were calculated as $22 \%$ and $43 \%$, respectively. Their reactions proceeded at the highest temperature of the network in low and moderate pressure conditions. In addition, the highest physical and chemical exergy rates were determined in SMR unit. The desired flow had the hydrogen molar fraction of $77 \%$ (Table A1). It is predicted that adding purification process data to the calculation could also tends to change in exergy efficiency more. Although the hydrogen fraction was not remarked, Silva and Oliveira calculated the exergy efficiency of SMR as about $77 \%$ by using pressure swing adsorption [41]. Contrast to SMR unit, adjusting the operating conditions of the outlet stream positively affected the vapor fraction in CCR unit and caused to increase hydrogen purity (88\%).

Considering the hydrogen consumption units, it can be remarked that HDS units have the lowest exergy efficiency (24\%, 32\% and 26\%) in the network. In these units, highmolecular-weight hydrocarbons is cleaned from sulphur compounds by hydrogen flow, and thus the desired products can be easily separated from the excess hydrogen flow contrary to other consumption units. HDS unit also has the lowest exergy efficiency in a previous study carried out in a different refinery plant [41]. NHT and ISO units, that involve high-quality naphtha in the desired stream, have high exergetic efficiency because of the absence of hydrogen recovery in the simulation. Naphtha is involving a mixture of hydrocarbon components ranging from $\mathrm{C}_{2}$ to $\mathrm{C}_{6}$. In order to the recovery of hydrogen from this mixture, many refiners normally use membrane and pressure swing adsorption (PSA) units. Even though cryogenic recovery is also feasible, the increased complexity in operating cryogenic units makes it unfavorable alternative unless recovery of light hydrocarbons is also desired [5]. If one of these types of recovery systems is added to the simulation, more practical exergetic efficiency could be calculated.

Similarly, the exergetic efficiency of HC unit was also determined as about 99\% due to the present of excess hydrogen in the desired product. Considering the desired products of $\mathrm{HC}$ unit, the reactor outlet streams are cooled in some exchangers and the vapor and liquid are separated in high-pressure and low-pressure separators to remove light ends in fractionation section. The low-pressure liquid is pumped to the recycle splitter flash drum and after heating in a furnace, it goes to recycle splitter for producing main products [36]. By adding this type of fractionation section to the simulation, the excess hydrogen, naphtha, kerosene, diesel and gasoline can be separated from the desired outlet stream, and thus practical exergetic efficiency could also be obtained. 
Table 4. Stream data of exergy analysis results

\begin{tabular}{|c|c|c|c|c|c|c|c|c|c|}
\hline Unit & $\begin{array}{l}\text { Stream } \\
\text { info }\end{array}$ & $\begin{array}{c}\text { Temperature } \\
\left({ }^{\circ} \mathrm{C}\right) \\
\end{array}$ & $\begin{array}{c}\text { Pressure } \\
\text { (bar) }\end{array}$ & $\begin{array}{c}\text { Vapor } \\
\text { Fraction } \\
\end{array}$ & $\begin{array}{c}\text { Mole Flow } \\
(\mathbf{k m o l} / \mathbf{h})\end{array}$ & $\begin{array}{c}\text { Mass Flow } \\
(\mathrm{kg} / \mathrm{h})\end{array}$ & $\begin{array}{c}\text { Physical Exergy Rate } \\
\text { (MW) }\end{array}$ & $\begin{array}{c}\text { Chemical Exergy Rate } \\
\text { (MW) }\end{array}$ & $\begin{array}{c}\text { Unit Efficiency } \\
(\%)\end{array}$ \\
\hline \multirow{2}{*}{ CCR } & $\mathrm{In}^{*}$ & 520 & 42 & 1 & 6.69 & 690.52 & 0.14 & 8.97 & \multirow{2}{*}{$22 \%$} \\
\hline & Desired Out $* *$ & 30 & 6 & 1 & 15.95 & 104.20 & 0.02 & 1.95 & \\
\hline \multirow{3}{*}{ SMR } & In & 840 & 20.6 & 1 & 9680.00 & 155293.92 & 91.19 & 2235.91 & \multirow{3}{*}{$43 \%$} \\
\hline & In & 214 & 20.6 & 1 & 18400.00 & 331481.15 & 93.69 & 4149.64 & \\
\hline & Desired Out & 30 & 6 & 1 & 45504.00 & 486775.07 & 53.71 & 2768.58 & \\
\hline \multirow{3}{*}{$\mathrm{HC}$} & In & 390 & 153 & 0 & 5.35 & 2180.45 & 0.25 & 28.17 & \multirow{3}{*}{$98 \%$} \\
\hline & In & 30 & 30 & 1 & 1659.68 & 6837.73 & 3.84 & 113.04 & \\
\hline & Desired Out & 30 & 6 & 1 & 1664.40 & 9018.20 & 1.99 & 178.27 & \\
\hline \multirow{3}{*}{ HDS-1 } & In & 340 & 35 & 0 & 2.23 & 391.86 & 0.03 & 5.10 & \multirow{3}{*}{$24 \%$} \\
\hline & In & 25 & 35 & 1 & 111.54 & 913.24 & 0.27 & 15.72 & \\
\hline & Desired Out & 30 & 6 & 0 & 2.26 & 387.36 & 0.00 & 5.07 & \\
\hline \multirow{3}{*}{ HDS-2 } & In & 360 & 35 & 0 & 2.23 & 591.06 & 0.06 & 7.67 & \multirow{3}{*}{$32 \%$} \\
\hline & In & 25 & 35 & 1 & 111.54 & 913.24 & 0.27 & 15.72 & \\
\hline & Desired Out & 30 & 6 & 0 & 2.29 & 590.49 & 0.00 & 7.68 & \\
\hline \multirow{3}{*}{ HDS-3 } & In & 360 & 65 & 0 & 17.85 & 5160.87 & 0.48 & 66.80 & \multirow{3}{*}{$26 \%$} \\
\hline & In & 30 & 65 & 1 & 1784.60 & 9104.67 & 5.06 & 184.28 & \\
\hline & Desired Out & 30 & 6 & 0 & 17.79 & 5126.81 & 0.00 & 66.62 & \\
\hline \multirow{3}{*}{ ISO } & In & 130 & 30 & 0.843 & 4.46 & 203.28 & 0.01 & 2.74 & \multirow{3}{*}{$98 \%$} \\
\hline & In & 30 & 30 & 1 & 200.77 & 444.75 & 0.47 & 13.67 & \\
\hline & Desired Out & 30 & 6 & 1 & 205.13 & 648.03 & 0.25 & 16.38 & \\
\hline \multirow{3}{*}{ NHT-1 } & In & 200 & 30 & 1 & 2.68 & 193.84 & 0.01 & 2.53 & \multirow{3}{*}{$99 \%$} \\
\hline & In & 30 & 30 & 1 & 26.77 & 73.90 & 0.06 & 1.99 & \\
\hline & Desired Out & 30 & 6 & 1 & 29.27 & 267.74 & 0.04 & 4.50 & \\
\hline \multirow{3}{*}{ NHT-2 } & In & 200 & 30 & 1 & 6.69 & 484.61 & 0.02 & 6.31 & \multirow{3}{*}{$99 \%$} \\
\hline & In & 30 & 30 & 1 & 66.92 & 184.75 & 0.16 & 4.98 & \\
\hline & Desired Out & 30 & 6 & 1 & 73.17 & 669.36 & 0.09 & 11.25 & \\
\hline \multirow{3}{*}{ NHT-3 } & In & 200 & 30 & 1 & 4.46 & 323.07 & 0.02 & 4.21 & \multirow{3}{*}{$99 \%$} \\
\hline & In & 30 & 30 & 1 & 44.62 & 123.16 & 0.10 & 3.32 & \\
\hline & Desired Out & 30 & 6 & 1 & 48.78 & 446.24 & 0.06 & 7.50 & \\
\hline \multirow{3}{*}{ NHT-4 } & In & 200 & 30 & 1 & 2.68 & 193.84 & 0.01 & 2.53 & \multirow{3}{*}{$99 \%$} \\
\hline & In & 30 & 30 & 1 & 93.69 & 258.64 & 0.22 & 6.97 & \\
\hline & Desired Out & 30 & 6 & 1 & 96.19 & 452.49 & 0.12 & 9.51 & \\
\hline
\end{tabular}

* "In" represents to inlet stream,

**"Desired Out" represents to desired outlet streams 


\section{Conclusions}

The proposed hydrogen network was created before by reducing the hydrogen surplus and matching only the hydrogen streams. However, in this study the reactor simulations and the reactions were considered by using exergy analysis. As a result, the chemical exergy flow rates were significantly (about 100 times) higher than physical exergy flow rates. Although the processes were carried out at the moderate and high operating conditions, the exergy efficiency of each unit was clearly affected by reactions in it. On the other hand, the exergy analysis results show that not only the hydrogen demand of units has to be reduced, but also the hydrogen recovery is very important for the efficiency of units. At this point, the purification systems and the new hydrogen recovery stream can be added to the simulation in order to obtain higher exergetic efficiencies.

\section{References}

[1]. Singh G., "Applied chemistry”, Discovery Publishing House, New Delhi, 2009.

[2]. Liu Y.A., Chang Ai-Fu, Pashikanti K. "Petroleum Refinery Process Modeling”, Wiley, ePDF ISBN: 9783-527-81336-0, 2018.

[3]. Valavarasu G., Sairam B. Light Naphtha Isomerization Process: A Review, Petroleum Science and Technology, 31:6 (2013), 580-595.

[4]. Karadag O., "Automatic gasoline blending system modelling at TUPRAS”, MSc. Thesis, Institute of Science, ITU, Istanbul, TR, 2008.

[5]. Treese A. S., Pujado P.R., Jones D.S.J, "Handbook of Petroleum Processing”, Springer Cham, Second edition, New York, 2006.

[6]. El-Gendy N.S., Speight J.G., "Handbook of Refinery Desulfurization”, CRC Press Taylor \& Francis Group, Boca Raton, 2016.

[7]. Zhang N. "Process Integration of an oil refinery hydrogen network”, In: Klemes J. editors. Handbook of Process Integration (PI), Woodhead Publishing, 2013.

[8]. Jin Q, Chen B., Ren Z., Liang X., Liu N., Mei D., “A theoretical study on reaction mechanisms and kinetics of thiophene hydrodesulfurization over MoS2 catalysts”, Catalysis Today 312 (2018), 158-167.

[9]. Lauritsen J.V., Kibsgaard J., Olesen G.H., Moses P.G., Hinnemann B., Helveg S., Nørskov J.K., Clausen B.S.,
Topsøe H., Lægsgaard E., "Location and coordination of promoter atoms in Co- and Ni-promoted MoS2based hydrotreating catalysts”, Journal of Catalysis 249, (2007) 220-233.

[10]. Elsherif M., Manan Z.A., Kamsah M.Z., "State-of-theart of hydrogen management in refinery and industrial process plants", Journal of Natural Gas Science and Engineering 24, (2015) 346-356.

[11]. Alves J.J. "Analysis and design of refinery hydrogen distribution systems”, PhD thesis, UMIST, University of Manchester, Manchester, UK, 1999.

[12]. Lou J., Liao Z., Jiang B., Wang J., Yang Y., “A thermodynamic irreversibility based design method for multi-contaminant hydrogen networks”, International Journal of Hydrogen Energy 40, (2015) 435-443.

[13]. Marques J.P., Matos H.A., Oliveira N.M.C., Nunes C.P., "State-of-the-art review of targeting and design methodologies for hydrogen network synthesis", International Journal of Hydrogen Energy 42, (2017) 376-404

[14]. Oduola M.K, Oguntola T.B., "Hydrogen pinch analysis of a petroleum refinery as an energy management strategy”, American Journal of Chemical Engineering, Special Issue 3, No. 2-1, (2015) 47-54.

[15]. Wall, G., Gong, M., "Exergy analysis versus pinch technology, efficiency, costs, optimization, simulation and environmental aspects of energy systems", in International Symposium on Efficiency, Costs, Optimization, Simulation and Environmental Aspects of Energy Systems (ECOS’96), June 25-27, 1996. Stockholm, 451-455.

[16]. Mert M.S., Dilmaç Ö.F., Özkan S., Karaca F., Bolat E., "Exergoeconomic analysis of a cogeneration plant in an iron and steel factory”, Energy 46 (2012), 78-84.

[17]. Dilmaç, Ö.F. and Özkan, S.K. “Energy and exergy analyses of a steam reforming process for hydrogen production”, Int. J. Exergy, 5, 2 (2008), 241-248.

[18]. Ozturk M., Dincer I. “Thermodynamic analysis of a solar-based multi-generation system with hydrogen production”, Applied Thermal Engineering, 51, (2013), 1235-1244.

[19]. Yuksel Y.E., Ozturk M., Dincer I., Thermodynamic analysis and assessment of a novel interated geothermal energy-based system for hydrogen production ans 
storage”, International Journal of Hydrogen Energy 43 (2018), 4233-4243.

[20]. Mert M.S., Yüksel F., Burulday M.E., "Biyokütle Kaynaklı Sentez Gazından Hidrojen Üretimine Entegre Bir Güç Sisteminin Modellenmesi”, Erzincan Üni. Fen Bilimleri Ens. Dergisi 12(2) (2019), 607-619.

[21]. Ishaq H., Dincer I., "Multi-objective optimization and analysis of a solar energy driven steam and autothermal combined reforming system with natural gas”, Journal of Natural Gas Science and Engineering 69 (2019), 102927, 1-19.

[22]. Agbo A. F, Aboje A. A, Obayomi K. S, Exergy analysis of Naphtha Hydrotreating Unit (NHU), 3rd International Conference on Science and Sustainable Development (ICSSD 2019) 1299 012025, 2019.

[23]. Rivero R. Application of the exergy concept in the petroleum refining and petrochemical industry, Energy Conversion and Management 43 1199-1220, 2002.

[24]. Akram A.U., Ahmad I., Chughtai A. Exergy Analysis and Optimization of Naphtha Reforming Process with Uncertainty, Int. J. of Exergy, 26 (3), 2018

[25]. Sadighi S., Mohaddecy S.R.S., Ghabouli O., Bahmani M. Revamp of Naphtha hydrotreating process in an Iranian Refinery, Petroleum \& Coal 51(1) 45-50 2009.

[26]. Mustafa, J., Ahmad, I., Ahsan, M. and Kano, M. "Computational fluid dynamics based model development and exergy analysis of naphtha reforming reactors”, Int. J. Exergy 24, (2017) Nos. 2/3/4, 344363.

[27]. Johanna Puolakka, K. and Krause, A.O.I. "CO2 reforming of n-heptane on a Ni/Al2O3 catalyst”, Studies in Surface Science and Catalysis 153, (2004), 329-332.

[28]. Ran, R., Xiong, G.X., Sheng, S.S. and Yang, W.S. “The effects of $\mathrm{CO} 2$ addition on the partial oxidation of heptane for hydrogen generation", Chinese Chemical Letters 15, No. 5, (2004), 605-608.

[29]. Abashar, M.E.E. "Low temperature catalytic reforming of heptane to hydrogen and syngas”, Journal of Saudi Chemical Society, King Saud University 20, (2016) S186-S195.

[30]. Worrell E., Corsten M., Galitsky C., "Energy efficiency improvement and cost saving opportunities for petroleum refineries”, in an Energy Star Guide for energy and plant managers, U.S. Environmental Protection Agency, Document Number 430-R-15-002, 2015. [Online] Available: http://www.energystar.gov [Accessed: July. 28, 2020]

[31]. Lou Y., Liao Z., Sun J., Jiang B., Wang J., Yang Y., “A novel two-step method to design inter-plant hydrogen network”, International Journal of Hydrogen Energy 44, (2019), 5686-5695.

[32]. Ozcelik Z., Karamandal N., "Hydrogen recovery system design application in a petrochemical refinery", Petroleum and Coal 61(6), (2019) 1414-1424.

[33]. Wu, S., Liu, G., Yu, Z., Feng, X., Liu, Y., Deng, C., "Optimization of hydrogen networks with constraints on hydrogen concentration and pure hydrogen load considered", Chemical Engineering Research and Design 90, (2012), 1208-1220.

[34]. Chen, B., Liao, Z., Wang, J., Yu, H., Yang, Y., "Exergy analysis and $\mathrm{CO} 2$ emission evaluation for steam methane reforming” International Journal of Hydrogen Energy 37, (2012) 3191-3200.

[35]. Wang Y., Wu S., Feng X., Deng C., “An exergy-based approach for hydrogen network integration”, Energy 86, (2015) 514-524.

[36]. Goodarzvand-Chegini F. and GhasemiKafrudi E., "Application of exergy analysis to improve the heat integration efficiency in a hydrocracking process", Energy \& Environment 28 (5-6), (2017) 564-579.

[37]. Mehdizadeh-Fard M., Pourfayaz F., Mehrpooya M., Kasaeian A., "Improving energy efficiency in a complex natural gas refinery using combined pinch and advanced exergy analyses” Applied Thermal Engineering 137, (2018) 341-355.

[38]. Wu S., Yu Z., Feng X., Liu G., Deng C., Chu K.H., "Optimization of refinery hydrogen distribution systems considering the number of compressors”, Energy 62, (2013) 185-195.

[39]. Bejan A., Tsatsaronis G., Moran M.J. “Thermal Design and Optimization” John Wiley, 1996, 113-167

[40]. Szargut J., Morris D.R., Steward F.R., “Exergy Analysis of Thermal, Chemical and Metallurgical Processes”, Hemisphere Publishing Corporation, New York, 1988. 
[41]. Silva J.A.M. and Oliveira Jr. S., “An exergy-based approach to determine production cost and $\mathrm{CO}_{2}$ allocation in refineries”, Energy 67, (2014), 607-616. 


\section{APPENDICES}

Table A.1. The mole fractions of streams for hydrogen production units

\begin{tabular}{|c|c|c|c|c|c|}
\hline \multirow[b]{2}{*}{ Compounds } & \multicolumn{2}{|l|}{ CCR } & \multicolumn{3}{|l|}{ SMR } \\
\hline & Inlet & Desired Outlet & Inlet & Inlet & Desired Outlet \\
\hline $\mathrm{H} 2$ & & 0.882 & & & 0.766 \\
\hline $\mathrm{CH} 4$ & & 0.038 & 1.000 & & 0.021 \\
\hline $\mathrm{C} 2 \mathrm{H} 6$ & & 0.030 & & & \\
\hline С3H8 & & 0.017 & & & \\
\hline C5H12-1 & & 0.027 & & & \\
\hline $\mathrm{C} 6 \mathrm{H} 14-1$ & 0.190 & trace & & & \\
\hline C6H12-2 & 0.010 & trace & & & \\
\hline C6H6 & & 0.003 & & & \\
\hline $\mathrm{CO} 2$ & & & & & 0.191 \\
\hline $\mathrm{H} 2 \mathrm{O}$ & & & & 1.000 & 0.021 \\
\hline C7H14-6 & 0.210 & trace & & & \\
\hline С8H16-8 & 0.460 & trace & & & \\
\hline C7H16-1 & 0.080 & trace & & & \\
\hline С8H18-1 & 0.050 & trace & & & \\
\hline C7H8 & & 0.002 & & & \\
\hline C8H10-3 & & 0.001 & & & \\
\hline
\end{tabular}


Table A.2. The mole fractions of streams for hydrocracking and hydrodesulphurization units

\begin{tabular}{|c|c|c|c|c|c|c|c|c|c|c|c|c|}
\hline \multirow[b]{2}{*}{ Compounds } & \multicolumn{3}{|l|}{ HC } & \multicolumn{3}{|c|}{ HDS-1 } & \multicolumn{3}{|c|}{ HDS-2 } & \multicolumn{3}{|c|}{ HDS-3 } \\
\hline & Inlet & Inlet & Desired Outlet & Inlet & Inlet & Desired Outlet & Inlet & Inlet & Desired Outlet & Inlet & Inlet & Desired Outlet \\
\hline $\mathrm{H} 2$ & & 0.90 & 0.9890 & & 0.700 & 0.003 & & 0.700 & 0.003 & & 0.850 & 0.004 \\
\hline $\mathrm{CH} 4$ & & 0.06 & 0.0080 & & 0.180 & 0.006 & & 0.180 & 0.006 & & 0.090 & 0.003 \\
\hline $\mathrm{H} 2 \mathrm{~S}$ & & & 0.0002 & & & 0.000 & & & trace & & & trace \\
\hline C2H6 & & 0.03 & 0.0020 & & 0.100 & 0.018 & & 0.100 & 0.018 & & 0.050 & 0.009 \\
\hline C3H8 & & 0.01 & 0.0005 & & 0.020 & 0.012 & & 0.020 & 0.012 & & 0.010 & 0.006 \\
\hline C4H10-1 & & & 0.0000 & & & & & & & & & \\
\hline C4H8-4 & & & & & & trace & & & trace & & & trace \\
\hline C2H6S-1 & 0.010 & & trace & 0.005 & & trace & 0.005 & & trace & 0.008 & & trace \\
\hline C2H6S2 & 0.010 & & & 0.005 & & trace & 0.005 & & trace & 0.008 & & trace \\
\hline C4H4S & 0.010 & & & 0.005 & & trace & 0.005 & & trace & 0.008 & & trace \\
\hline C8H6S & 0.010 & & trace & 0.005 & & trace & 0.005 & & trace & 0.008 & & trace \\
\hline C12H8S & 0.010 & & & 0.005 & & trace & 0.005 & & trace & 0.008 & & trace \\
\hline C8H10-4 & & & trace & & & 0.004 & & & 0.004 & & & 0.005 \\
\hline $\mathrm{C} 12 \mathrm{H} 22$ & & & trace & & & 0.005 & & & 0.005 & & & 0.008 \\
\hline С9H20-1 & & & & 0.122 & & 0.113 & & & & & & \\
\hline $\mathrm{C} 10 \mathrm{H} 22-1$ & & & & 0.122 & & 0.118 & & & & & & \\
\hline $\mathrm{C} 11 \mathrm{H} 24$ & & & & 0.122 & & 0.120 & & & & & & \\
\hline C12H26 & & & & 0.122 & & 0.120 & & & & & & \\
\hline $\mathrm{C} 13 \mathrm{H} 28$ & & & & 0.122 & & 0.121 & & & & & & \\
\hline C14H30 & & & & 0.122 & & 0.121 & & & & & & \\
\hline C15H32 & & & & 0.122 & & 0.121 & & & & & & \\
\hline С16Н34 & & & & 0.121 & & 0.120 & & & & & & \\
\hline $\mathrm{C} 21 \mathrm{H} 44$ & & & & & & & & & & 0.960 & & 0.963 \\
\hline С18Н38 & & & & & & & 0.475 & & 0.463 & & & \\
\hline $\mathrm{C} 2 \mathrm{OH} 42$ & & & & & & & 0.500 & & 0.487 & & & \\
\hline C30H62 & 0.950 & & trace & & & & & & & & & \\
\hline
\end{tabular}


Table A.3. The mole fractions of streams for naphtha hydrotreating and isomerization units

\begin{tabular}{|c|c|c|c|c|c|c|c|c|c|c|c|c|c|c|c|}
\hline \multirow[b]{2}{*}{ Compounds } & \multicolumn{3}{|l|}{ ISO } & \multicolumn{3}{|c|}{ NHT-1 } & \multicolumn{3}{|c|}{ NHT-2 } & \multicolumn{3}{|c|}{ NHT-3 } & \multicolumn{3}{|c|}{ NHT-4 } \\
\hline & Inlet & Inlet & Desired Outlet & Inlet & Inlet & Desired Outlet & Inlet & Inlet & Desired Outlet & Inlet & Inlet & Desired Outlet & Inlet & Inlet & $\begin{array}{l}\text { Desired } \\
\text { Outlet } \\
\end{array}$ \\
\hline $\mathrm{H} 2$ & 0.090 & 0.90 & 0.9693 & & 0.700 & 0.863 & & 0.700 & 0.863 & & 0.700 & 0.863 & & 0.700 & 0.930 \\
\hline $\mathrm{CH} 4$ & 0.191 & 0.06 & 0.0124 & & 0.180 & 0.032 & & 0.180 & 0.032 & & 0.180 & 0.032 & & 0.180 & 0.031 \\
\hline $\mathrm{H} 2 \mathrm{~S}$ & 0.013 & & 0.0003 & & & 0.005 & & & 0.005 & & & 0.005 & & & 0.002 \\
\hline $\mathrm{C} 2 \mathrm{H} 6$ & 0.199 & 0.03 & 0.0065 & & 0.100 & 0.010 & & 0.100 & 0.010 & & 0.100 & 0.010 & & 0.100 & 0.009 \\
\hline С3H8 & 0.057 & 0.01 & 0.0017 & & 0.020 & 0.001 & & 0.020 & 0.001 & & 0.020 & 0.001 & & 0.020 & 0.001 \\
\hline C4H10-1 & 0.113 & & 0.0008 & 0.300 & & 0.027 & 0.300 & & 0.027 & 0.300 & & 0.027 & 0.300 & & 0.008 \\
\hline $\mathrm{C} 5 \mathrm{H} 12-1$ & 0.140 & & 0.0006 & 0.300 & & 0.027 & 0.300 & & 0.027 & 0.300 & & 0.027 & 0.300 & & 0.008 \\
\hline C6H14-1 & 0.175 & & 0.0007 & 0.300 & & 0.029 & 0.300 & & 0.029 & 0.300 & & 0.029 & 0.300 & & 0.009 \\
\hline C4H8-4 & 0.005 & & trace & 0.014 & & 0.001 & 0.014 & & 0.001 & 0.014 & & 0.001 & 0.014 & & trace \\
\hline C5H10-1 & 0.006 & & trace & 0.014 & & 0.001 & 0.014 & & 0.001 & 0.014 & & 0.001 & 0.014 & & trace \\
\hline C6H12-2 & 0.011 & & trace & 0.014 & & 0.002 & 0.014 & & 0.002 & 0.014 & & 0.002 & 0.014 & & 0.001 \\
\hline C6H6 & & & & 0.018 & & trace & 0.018 & & trace & 0.018 & & trace & 0.018 & & trace \\
\hline C2H6S-1 & & & & 0.020 & & trace & 0.020 & & trace & 0.020 & & trace & 0.020 & & trace \\
\hline C2H6S2 & & & & 0.020 & & & 0.020 & & & 0.020 & & & 0.020 & & \\
\hline C6H14-2 & & & 0.0025 & & & & & & & & & & & & \\
\hline C6H14-5 & & & 0.0008 & & & & & & & & & & & & \\
\hline C4H10-2 & & & 0.0019 & & & & & & & & & & & & \\
\hline C5H12-2 & & & 0.0024 & & & & & & & & & & & & \\
\hline
\end{tabular}

